\title{
JOHN EVELYN AND MEDICINE*
}

\author{
by
}

\section{D. O’MALLEY}

JoHN EVELYN has often been described as a virtuoso in the seventeenth-century meaning of that word, and if it be recalled that the Earl of Arundel, the greatest of the virtuosi, was his patron, that Evelyn was a member of the Royal Society almost from its inception and a diligent attendant of its meetings, which at that time dealt with a wide variety of curiosa and technological as well as scientific problems, that he was a vocal and literary exponent and collector of the odd and the artistic, and a recognized authority on architecture and gardens, he must certainly be classed among the notable virtuosi of his day. But within his multifarious interests and their related activities Evelyn appears to have had a particular regard for medicine, one that transcended the usual concern of those members of his class who did not espouse that subject professionally. Except for somewhat intermittent studies at Oxford, undertaken more as an obligation than because of genuine desire, medicine was the only discipline in which he deliberately took any formal instruction, and throughout the many years covered by his Diary medicine and matters ancillary to it received uncommon attention. ${ }^{1}$

Anyone living in the seventeenth century was very much aware of accident, disease, and ever proximate death. It was quite in the order of things that Evelyn, born in 1620 , recalled from his fifth year the severe plague in 1625 , its high mortality and the fact, as he later wrote, that he himself 'was shortly after so dangerously sick of a Feavor, that (as I have heard), the Physitians despair'd of me' (ii.7). ${ }^{2}$ He was fourteen years old when his sister Elizabeth died (ii.12), fifteen at the death of his mother, whose four attending physicians were identified by name in the Diary (ii.14-15), and twenty at the time of his father's death (ii.26). Of Evelyn's five sons, four died in infancy and he outlived the fifth. Of three daughters, two died as young women, and only one outlived her father. This chronicle of sickness and high mortality was common enough at the time, but Evelyn appears to have differed from other contemporary diarists and chroniclers in the detail he devoted to the causes, actual or presumed, of sicknesses and their treatments, and more frequent identification of the attending physicians.

In addition to such references, he seems to have known, often intimately, not only the leading members of the medical profession but as well many of those practising in the provinces. The one great exception was Thomas Sydenham who is never

* The Sydenham Lecture, given at Apothecaries' Hall on 21 November 1967.

1 The only previous study of Evelyn in relation to medicine is that of Leonard Guthrie, "The medical history of John Evelyn, D.C.L., F.R.S., and of his time (1620-1706)', Med. Mag., Lond., $1904,13,309-19,468-78,667-89$. There are several brief papers dealing with more or less specific topics: H. G. Adamson, 'John Evelyn's account of a case of dermatitis ficta', Br. J. Derm., 1937, 49, 435-36; and W. S. O'Kelly, 'Pepys, Evelyn, and Lady Montague on smallpox', Ir. J. med. Sci., 1941, 97-107 (March).

2 This and the following enumerations within the text refer to volume and page of John Evelyn's Diary. Now first printed in full from the MSS. belonging to John Evelyn, ed. E. S. de Beer, Oxford, 1955, 6 vols. 


\section{D. O'Malley}

mentioned in the Diary, but this is probably explained by the fact of Evelyn's strong monarchist sympathies in contrast to his identification of Sydenham with the puritan revolution and the Commonwealth.

Whether or not Evelyn was a physician manqué, some of his interest in medicine was also owing to the humanitarian bent of his character. From an early age he displayed a lively concern with hospitals and the care of the infirm. It was, furthermore, a concern that surpassed that of other like-minded members of his class since he seems to have been not only willing but even determined to learn by observation every aspect of hospital activities, even though the more gruesome brutalities of seventeenth-century surgery were occasionally almost too much for such worthy resolution. In 1672, as a commissioner for the care of sick and wounded seamen of the Anglo-Dutch war, he watched and described how a surgeon 'cut off a poore creaturs Leg, a little under the knee, first cutting the living \& untainted flesh above the Gangreene with a sharp knife, and then sawing off the bone in an instant; then with searing \& stoopes stanching the blood, which issued aboundantly; the stout \& gallant man, enduring it with incredible patience, $\&$ that without being bound to his chaire, as is usual in such painefull operations, or hardly making a face.' One such experience was enough for Evelyn, however, who continued, 'I had hardly courage enought to be present, nor could I endure to se any more such cruel operation' (iii.610).

In July 1641, several months short of his majority, Evelyn made a trip to the Netherlands where in Rotterdam he had his first sight, among other things, of an elephant and observed that contrary to vulgar tradition it was 'flexible and nimble in the joynts' (ii.39), as, incidentally, Sir Thomas Browne would point out five years later in his Pseudodoxia epidemica. More important was Evelyn's visit to Amsterdam where he inspected several hospitals and especially noted the 'Hospitall for their lame and decrepid souldiers ... one of the worthiest things that I thinke the worlde can shew of that nature' (ii.45). Forty years later the memory of this hospital remained an incentive to Evelyn's share in the foundation of Chelsea Hospital. Returned to Leyden, he matriculated in the university where, although he undertook no studies, he was much impressed by the medical school, its physic garden, and especially by the anatomical theatre and museum. On a later occasion when the Duke of York told him of a woman who had swallowed an ear of barley that eventually worked out of her side (iii.306), Evelyn was able to recall and describe a knife he had seen at Leyden twenty years earlier, as he had noted in his Diary at the time, 'newly taken out of a Drunken Dutch-mans gutts, by an incision in his side, after the sottish fellow had swallow'd it' (ii.53).

This first continental visit was a brief one from which Evelyn returned to England in October, but in 1644, realizing that despite his loyalty to Charles I he was not temperamentally suited to the military life that was then becoming incumbent upon the king's supporters at home-and even though the Evelyn fortune was based upon the manufacture of gunpowder-he returned to the continent where he remained for about two years.

In Paris he found the hospitals to be of a size unknown in England, and in a remark that needs no commentary related that the sick were treated 'decently and Christianly 


\section{John Evelyn and Medicine}

... yea even to delicacy' (ii.101). The Paris hospitals were famous, too, for the practice of lithotomy, and on a further visit in 1650 Evelyn was able to watch and describe the entire operation on a 'person of 40 years old [who] had a stone taken out of him, bigger than a turkys Egg', and 'a little Child of not above 8 or 9 yeares age, with much cherefullnesse, going through the operation with extraordinary patience, \& expressing greate joy, when he saw the stone was drawn' (iii.3-4). Evelyn's reaction to what he had seen was 'to give Almighty God hearty thankes, that I had not ben subject to this Infirmitie, which is indeede deplorable', as in fact he was to learn by personal experience in later years.

But of all the hospitals Evelyn visited on his European tour none other impressed him as much as Christ's Hospital in Rome for size, equipment and its unusually large attending staff of ninety, 'the most pious and worthy Foundation I ever saw' (ii.311-12). Moreover, as he was quick to realize, since young physicians and surgeons had free access to the patients, it was undoubtedly a valuable instrument for the teaching and study of clinical medicine. One of Evelyn's guides through this and other Roman hospitals was Dr. Matthew Bacon of Norfolk, a recent M.D. of Padua then living in Rome and later, in 1664, to become an honorary Fellow of the College of Physicians of London.

Eventually Evelyn reached Venice where, as well as in nearby Padua, he remained for nearly ten months. An early visit to the physic garden of the Paduan medical faculty led him to request the preparation of a volume of dried plants which years later Samuel Pepys was to declare 'better than an herball'. It was only a short distance in imagination and knowledge from a general interest in gardens and gardening to the more specialized garden of medicinal plants, and Evelyn never missed an opportunity to visit the physic gardens of Paris, Leyden, Westminster, Chelsea, Oxford, or wherever his travels took him; and it is very likely that he knew more about the herbal ingredients of seventeenth-century remedies than did most of the physicians of his day.

The Paduan medical faculty was still the most famous in Europe and the source of the medical degrees held by many of England's most famous physicians from Linacre and Caius to William Harvey who was still living at this time although, it appears, he was not personally known to Evelyn. However, Evelyn must have seen Harvey's stemma in the university's arcade, and it is likely that he had learned something of 'little Dr. Harvey' from the Earl of Arundel whom Harvey had accompanied on his continental trip in 1636; undoubtedly, too, he would learn much from Sir Charles Scarburgh, Evelyn's friend of later years. The chair of anatomy that had first gained prominence under Vesalius and retained its distinction under his successors was now held by the German Johannes Vesling, whose Syntagma anatomicum, to be published in 1647 and thereafter translated into several vernacular languages, would remain a standard anatomical textbook for about a half-century. Evelyn matriculated in Padua primarily for the sake of Vesling's course which lasted for a month and during that time watched the dissection of a man, a woman, and a child in the famous anatomical theatre of Fabricius (ii.475).

Evelyn retained his interest in anatomical studies, and undoubtedly his Paduan training provided him with a greater appreciation of such later events as the dissection 


\section{D. O'Malley}

he watched in the home of the surgeon James Moulin in 1649 (ii.553), and George Joyliffe's investigation of the lymphatic system. (ii.551).

Since the Paduan anatomical demonstrations took place in the morning, he was able to observe the treatment of patients in the hospital of San Francesco during the afternoon 'by Trepanning, Launcing, Salivating, Sweating, \&c.'. Unfortunately many of the patients were overbold women brought to the hospital as a result of their imprudent lives so that the modest-perhaps slightly prudish-young Englishman declared 'I do not approve of their so freely admitting young Gentlemen Travellers to see their operations upon some of the female Sex, who even in the midst of their tortures, are not very modest, $\&$ when they begin to be well, plainely lew'd' (ii.476). Evelyn's unusual modesty for one with strong medical interests remained with him; when a hermaphrodite who 'shew'd both Sexes very perfectly' was displayed in London in 1667, he noted that 'divers curious persons went to see her, but I would not' (iii.492).

More pleasant as a memento of Padua were the four panels of preparations of human veins and nerves dissected out and prepared by Giovanni Leoni, surgeon and assistant to Vesling and now to be seen in the Royal College of Surgeons of England. As they reflected Evelyn's interest in anatomy and anatomical technique, so too they were appreciated in England where Dr. Scarburgh vainly sought them as a gift for the College of Physicians (iii.77) or alternately a purchase for which the Marquis of Dorchester agreed to supply the funds. But Evelyn, ever faithful to the Royal Society, presented the panels to that body in 1667 (iii.501), and an account of them by the surgeon William Cowper, published in the Philosophical Transactions in 1702, fifty-six years after their acquisition in Padua, must have been especially gratifying to the still living but aged donor. The account contains a statement by Evelyn that Leoni had been willing to dispose of the panels only because of his imminent departure from Padua and that Evelyn bought them with the understanding that the surgeon would add to and complete the fourth panel by the addition of 'the liver, gastrick nerves and other vessels'.

Throughout his youth Evelyn seems not to have been much handicapped by illnesses except for an undescribed fever when he was about five years old, and a bout of malaria in 1638 which kept him away from Oxford for several months (ii.22) and was to recur from time to time in later years. In Padua he suffered from a quinsy that 'had almost cost me my life', which he attributed to his drinking wine in the Paduan manner, that is, 'coold with Snow \& Ice'. The famous Vesling was unsuccessful in his treatment of Evelyn's case, and it was only after Benedetto Selvatico 'that famous Physitian' had taken over and 'made me be cupp'd \& scarified in the back in 4 places', and the passage of a fortnight that Evelyn was fully recovered (ii.472).

Not much later, in the course of returning to England by way of Switzerland, he came down with smallpox in Geneva and was compelled to remain in that city for five weeks under the care of the Swiss physician Etienne le Duchat. It was a relatively mild case during which the patient was chiefly disturbed upon suddenly awakening by the sight of his nurse who had a large goitre (ii.521-22).

Throughout the remainder of his long life Evelyn was subject to two chronic complaints, haemorrhoids and malaria. The former was first revealed in a combined 


\section{John Evelyn and Medicine}

account of his smallpox and a suggested regimen for the future prepared by his Genevan physician (ii.530-32), who mentions in it the application of leeches to the seat of Evelyn's trouble. The victim usually sought to prevent or to control the onset of this painful complaint by bleeding himself for what he described on one occasion as 'my often infirmitie of the Eemeroides' (iii.38). He was still plagued at the age of eighty-three (v.552).

With malaria endemic in seventeenth-century England it is not astonishing that Evelyn was a victim of that disease which he calls variously ague, ague-like attacks, tertian, double tertian, and quartan ague. Troubled by it from his youth until his final years, he usually treated his own case by remaining indoors or taking to his bed. Occasionally outside assistance was summoned, as in 1653 when Dr. Edmund Wilson plied Evelyn 'with Physick' (iii.81). In 1660, during a particularly severe attack, he was attended by Drs. Wedderburn, Claud, and his old friend Jasper Needham (iii.243). In 1682 he used a prescription of his own so that after three bouts of an 'Ague Tertian . . . bathing my leggs to the knees in Milk made as hott as I could endure it, \& sitting so in it, in a deepe Churn or Vessell, covered with blanquets \& drinking Carduus posset, then going to bed sweating, I not onely missed that expected fit, but I had no more' (iv.272). Curiously enough Evelyn never mentions his use of the Jesuits' Powder, as he calls it, although he was aware of its preparation by Talbor and had been present at a meeting of the Royal Society where the efficacy of the preparation of the bark had been discussed favourably. In 1685 he had seen in the 'Apothecaries Garden . . . at Chelsey ... the Tree bearing the Jesuits bark, which had don such cures in quartans' (iv.462).

From about the age of sixty Evelyn began to suffer from gravel and stone. In 1682 he noted in his Diary that ' $I$ was this day exceedingly paind in both my kidnies, which gave me apprehension of some farther evil, which God in mercy avert' (iv.275). His apprehension was justified since through the remaining quarter-century of his life he made many references to nephritic pain and the dire effects of the stone.

Other than these kinds of sickness Evelyn was bothered by nothing more severe than occasional colds, gastrointestinal upsets, several fainting spells such as that following his reluctant participation in a 'Dutch feast' (iv.296), vertigo usually associated with fatigue, bouts of constipation as he became older, minor aches and pains, and occasional accidents. If he had been asked to explain his unusual freedom from sickness, relative to the age in which he lived, and the secret of his longevity that endured almost to his eighty-sixth year, he would no doubt have ascribed it to his abstemious way of life and to his use of what he called preventive medicine, either what he refers to simply as 'physick' or to the letting of some ounces of blood periodically.

He appears to have had sufficient confidence in his own medical knowledge to undertake this practice, or perhaps experience had suggested to him that his selfdirected measures were no less effective than those of qualified physicians. In 1649, after 'I fell dangerously ill of my head, was blisterd, \& let blood, \& behind the Eares and forehead', and when 'All the Physitians had done their best' to no avail, Evelyn undertook his own treatment 'by using the fumes of Cammomile on Embers applied 


\section{D. O'Malley}

to my Eares' (ii.554). His success, at least to his own satisfaction, may have emboldened him so that in 1653 he began an annual routine, no doubt desirable for hygienic reasons whatever its medical value. 'I first began a Course of yearely washing my head with Warme Water, mingld with a decoction of Sweete herbs, \& immediately with cold Spring water, which much refreshd me, \& succeeded very well with me divers yeares' (iii.87). In a letter of 1668 he revealed that he was still continuing this practice which was, as he wrote, 'an incredible benefit to me the whole year after', and that it 'preserved [my hair] bright and clean.'3 It is only just to say that he performed this ablution more than once a year, although only during the summer.

In 1652 Evelyn did refer to a consultation with Dr. Henry Stanley, a local physician, whereafter 'I went home and tooke Physick' (iii.62), and in 1657 he referred to an occasion on which he made a trip to London specifically 'to consult Dr. [George] Bate about taking preventing physick' (iii.191). If one may judge Bate's views at this period by the posthumously published Pharmacopoeia Bateana, one would hope that Evelyn as a man of common sense gained further determination to remain as much as possible his own physician. Later entries in the Diary indicate that this was to some degree his course, and it is clearly declared in a letter of 1700 to Samuel Pepys, in which, referring to his suffering from strangury, Evelyn declared with the wisdom of eighty years that he had 'hitherto consulted no other doctors than now and then a clyster [or] an ounce of manna.' In fact, rather than present his ailment to the medical profession, he wrote, 'I relate my present and naked case to you, who I am perswaded may have by you some excellent remedy.'

As Evelyn was often his own physician, so it was not unnatural that his interest in physic gardens extended beyond their raw material to the finished product, the prepared drug or remedy. In 1644 he took advantage of his visit to Venice to buy and bring home with him some of its famous treacle, 'the making and extraordinary ceremonie whereof, I had ben curious to observe, for tis extremely pompous \& worth seeing' (ii.478). On the occasion of a visit to London in 1659 he went to see the 'severall Drougs for the confection of Treacle, Diascordium \& other Electuaries which an ingenious Apothecarie had not onely prepard, \& ranged upon a large \& very long table, but coverd every ingredient with a sheete of paper, on which was very lively painted the thing, in miniature very well to the life, were it plant, flower, Animal, or other exotic drough' (iii.235-36). The apothecary had need certainly of a very long table since any one of his several preparations contained dozens of ingredients, but there is no indication that Evelyn's interest was based upon belief in the reputed value of such drugs as panaceas or antidotes against poisons. He seems rather to have been interested in them because of their long and curious histories stretching back to antiquity. A little later in the century Gideon Harvey would reveal the specious nature of the claims for such remedies and specifics which, ${ }^{5}$ so it seems, the nastier the contents the greater the presumed virtue. Viper's flesh, for instance, was now in great vogue in England as it was in France, and was one of the ingredients

\footnotetext{
- Memoirs . . . of John Evelyn ... and a Selection of his Familiar Correspondence, ed. William Bray, London, 1863, III, pp. 208-9.

Private Correspondence and Miscellaneous Papers of Samuel Pepys, ed. J. R. Tanner, London, 1926, II, pp. 20-21.

- The Diseases of London, London, 1675.
} 


\section{John Evelyn and Medicine}

of Sir Walter Raleigh's Cordial upon which Le Fèvre, the royal apothecary, once lectured before the king with Evelyn in attendance (iii.336).

These drugs were primarily herbal in content, the so-called galenicals, long in use and many of them known to Evelyn from their extensive literary histories as well as their employment. Chemical remedies represented the novelty of the age, the Paracelsian heritage then being developed by alchemists and chemical apothecaries. Despite the intense and bitter rivalry between the supporters of the new spagyric school and the tradition-bound Galenists, whom Evelyn as a conservative normally supported, his insatiable curiosity required him to investigate the new therapy.

In 1647 in Paris on his way home from Padua, Evelyn attended 'a Course of Chymistrie' given by Nicasius le Fèvre, that later apothecary to Charles II (ii.534). During his next visit to Paris in 1651 he was again to be found at Le Fèvre's course which was also attended at that time by Sir Kenelm Digby (iii.49). On one occasion in 1658 when Evelyn was 'sick of a sore throat \& feavor, which made me keepe my bed 4 or 5 dayes' he took a preparation of antimony (iii.220), and in 1666 when indisposed he 'entred into a Course of Steele' (iii.464) $;{ }^{6}$ but for the most part he appears to have been sceptical or at least reserved judgment over the merits of the alchemists and chemical apothecaries. As early as 1644 when in Florence and shown an iron nail of which half was said to have been converted alchemically into gold by Leonhard Thurneisser, Evelyn was quick to note that the golden part was in fact soldered to the iron (ii.192). As for the iatrochemical activities of Sir Kenelm Digby, Evelyn's reaction was that 'Sir Kenhelme, was an arrant Mountebank' (iii.48).

Experimental chemistry, the investigation of the properties of various acids and salts as carried out in the meetings of the Royal Society was a wholly different matter in which Evelyn had the deepest interest and of which he recognized the value. But when he regretted that the potable gold sent him from Paris by Claude Roussell had all leaked out of its phial en route so that he received nothing but a letter explaining the method of giving the remedy and, as he wrote, 'the stupendious cures it had don at Paris', his regret was for the loss of a curiosity rather than of a medicine of any value (iii.86-87).

The same common-sense attitude led him to oppose some of the still widely held superstitions of his day. He denied the validity of astrology and termed its practitioners 'knavish and ignorant star-gazers' (iii.63), which certainly placed him in advance of some of the physicians of that period. As an orthodox member of the Anglican church he could not deny the possibility of miracles, but his personal attitude appears to have been much like that of James II who, as Evelyn reported of a conversation with the king, was very chary of such things 'for feare of being impos'd on, that if he should chance to see [a miracle] himself, without some other witnesse, he should apprehend it some delusion of his senses' (iv.468). Evelyn did not express his personal opinion of the little Dutch boy exhibited in 1701, the iris of one eye said to be encircled by the words Deus meus, and of the other by Elohim in Hebrew characters, but his reservation suggests doubt. 'Everybody went to see this unusual phenomena',

- The 'Course of Steele' was an infusion of iron or steel filings in Rhine wine, much favoured by both Sydenham and Willis. Leonard J. Goldwater, 'A short history of iron therapy', Ann. med. Hist., 1935, 7 (n.s.), 263. 


\section{D. O'Malley}

he wrote, 'Physitians \& philosphers with greate accuracy examining it, some affirmed it artificial, others tooke it for something almost supernaturall' (v.453).

Nor did Evelyn know the explanation, although he presumed there must be a rational one, in the case of a neighbour's maid-servant who after feeling a blow on her arm discovered the skin to be covered with small reddish crosses, and "the rest of the arme livid \& of a mortified hue with certaine prints as it were of the stroke as of fingers.' Evelyn was acquainted, so he continued, with the case of the 'impostorious Nunns of Loudune', but the maid-servant although subject to convulsive fits, appeared to him to be of a different sort, and 'I knew not what to think of it; nor dare I pronounce it any thing supernaturall' (iii.556-57). In addition to this possible instance of urticaria factitia, in the same year Evelyn reported Lord Stafford's allergy to roses which caused him to depart 'in some disorder' from a dinner table 'because there were roses stuck about the fruite'. To Evelyn this strange action represented merely antipathy, and his reply to Sir Kenelm Digby's story that 'laying but a rose upon [Lady Selenger's] Cheese, when she was a sleepe it raisd a blister' was that 'Sir Kenhelme was a teller of strange things' (iii.550). On this latter occasion Evelyn's rationalism led him astray whereas Digby, perhaps a mountebank, as Evelyn described him, was factually correct in his report.

Although Evelyn was often his own physician, he was much readier to seek qualified medical assistance for the other members of his family. Nevertheless there were occasions when he felt confident in his medical role or when circumstances required him to act. In 1652 after 'hearing the Small-pox was very rife in and about Lond: and that my Lady had a greate desire to drink Tunbridge Waters: I carried [her] thither' (iii.68). He had of course done no more than any physician would have recommended he do in time of pestilence, that is, to flee to some uninfected spot-indeed, physicians were often criticized for too freely following this advice themselves. As for the supposed therapeutic value of the waters, Evelyn appears to have placed little faith in that of any of the numerous English spas, visiting them as an escort to his wife and as an interested observer of a pseudo-medical but actually social phenomenon. He never refers to any therapeutic benefit received. Indeed, he remarked in a letter of 1668 that when in Italy 'I did sometimes frequent the public baths . . . but seldom without peril of my life, till I used ... [a] profusion of cold water before I put on my garments, or durst expose myself to the air'. ' In 1654 'We all went to see Bathe, where I bathed in the Crosse bathe' (iii.101). At the time neither Evelyn nor any of the accompanying members of his family was ill, and the fact that he bathed in the 'Crosse bathe' merely called attention to the fact that he had entered that one reserved for the gentry.

Later in that same year a near-catastrophe at his home at Sayes Court revealed Evelyn as cool-headed in an emergency and displaying as much ingenuity as might have been demonstrated by the surgeon he sought but could not reach.

By Gods special Providence we went not to Church ... f for my little sonne Richard now about 2 yeares old as he was fed with broth in the morning, a square but broad \& pointed bone ... . stuck so fast in the Childs Throate \& cross his Weason, that had certainely choaked him ... for his mayd being alone with him above in the Nurserie, was fallen downe in a swone, when we

' Memoirs, op. cit., III, p. 209. 


\section{John Evelyn and Medicine}

below ... heard an unusual groaning over our head, upon which we went up, \& saw them both gasping on the floore, nor had the Wench any power to say what the Child ail'd or call for help; at last she sayd, she believed a Crust of bread had choak'd her little Master, so it almost had, for the eyes \& face were swollen, \& clos'd, the Mouth full of froath, and gore, the face blackno Chirurgeon heere: what should we doo? We cald for drink, power it downe, it returnes againe, the poore babe now neere expiring. I hold its head down, incite it to Vomite, it had no strength. In this dispaire ... that so unknown \& sad an accident should take from us so pretty a Child: It pleased God, that on the suddaine effort $\&$ as it were struggling his last for life, he cast forth a bone (iii. 145-46).

Despite survival on this occasion the child was not destined to live for long, and as in this first instance the surgeon was beyond call, so at its death about four years later qualified medical help was also unavailable since although 'we sent for Physitians to Lond, whilst there was yet life in him; but the river was frozen up, \& the Coach brake by the way ere it got a mile from the house.' Young Richard Evelyn seems to have been a victim of malaria and his death was hastened, according to his father, by the fact that he was 'coverd too warme ... . and by a greate fire in the roome' (iii.206). If Evelyn's belief that a patient with fever should not be aggravated by further artificially induced heat was good sense, it was also unwittingly endorsement of Sydenham's 'cooling treatment'.

On occasion Evelyn was cast in the role of advocate of medical assistance rather than actual practitioner. In 1669 his brother Richard was very ill with the stone but refused to accept surgical treatment. Realizing the seriousness of Richard's condition and the apparent futility of any other measure except surgery, 'I went that evening to Lond: to carry Mr. Pepys to my Bro: . . w who himselfe had been successfully cut: $\&$ carried the Stone (which was as big as a tenis-ball) to shew him, and encourage his resolution to go thro the operation' (iii.529). But despite this living example of the value of lithotomy, Richard Evelyn remained, in the words of the diarist, 'averse from being cut, which he was advised to undergo from time to time, with extraordinary probability of successe: but when it came to the operation, \& all things prepared, his spirit \& resolution failed' (iii.543-44). Richard Evelyn died on 6 March and on the 8th a postmortem examination took place, but 'it was not a specctacle I desir'd to be present at'. Nevertheless the diarist was not unwilling to record the details of the medical findings, including the fact that 'a stone was taken out of his bladder, not much bigger than a nutmeg, somewhat flatt, \& oval, not sharp, one part excepted, which was a little rugged' (iii.544).

The illness and death from puerperal fever in 1678 of Evelyn's young friend Mrs. Godolphin also reveals him in the middle of a medical emergency that at that time could have had only one conclusion. The first physician called was quickly recognized as inexperienced in such matters, and the second, lacking confidence in his own ability, refused to undertake any measures except in consultation with others of more experience. Dr. Lower had been summoned, but after a long delay it was discovered that he was elsewhere on a case; by then it was far into the night and other physicians excused themselves on the grounds of exhaustion from their day's labours. Finally through Evelyn's persistence his old friend Jasper Needham arrived, although himself ill, and Dr. Thomas Short, one of the royal physicians, but by then, wrote Evelyn, Mrs. Godolphin was 'in a manner spent, and no't could physitians doe, when neither 


\section{D. O'Malley}

the cupping nor the pidgeons, those last remedyes, wrought any effect'. ${ }^{8}$ With the death of Mrs. Godolphin, and her husband in a state of collapse, Evelyn's part was not yet finished, since 'the Fees to the Physitians ... was wholy committed to me' (iv.151).

It would appear that in emergencies qualified medical assistance was not always easy to come by, and Evelyn's medical knowledge must frequently have been called for. When in 1688 his daughter Susanna was jolted from the family carriage so that the rear wheels ran over both her thighs, it seems to have been Evelyn who, as he wrote, 'let her blood, anointed, and made her keepe bed 2 days' (iv.569).

When assistance could be obtained, however, Evelyn sought what he considered the best. When his last surviving son John fell ill in 1679, Jasper Needham, family friend as well as distinguished physician, was called (iv.180). When Evelyn's daughter Mary came down with smallpox in 1685, her father summoned Dr. Thomas Short who had been involved in the earlier Godolphin case. Evelyn described him as 'the most approved \& famous Physition of all his Majesties Doctores' (iv.420), an opinion with which Sydenham expressed concurrence. Dr. Short's pessimistic prognosis of Mary Evelyn's illness was fulfilled, although, as her father noted, her demise could have been avoided if she had accepted Harvey's warning that young people subject to smallpox ought to be bled; but whether this admonition, to be found in De generatione animalium, was quoted by Dr. Short or had already been known to Evelyn from that copy of the book he possessed we are not aware (iv.425).

In 1694 when Evelyn's surviving daughter Susanna appeared to have developed serious complications after giving birth, Sir Thomas Millington, also admired by Sydenham and praised in Garth's Dispensary, was in attendance, as well as Salusbury Cade, at the time young and therefore probably available (v.190). In 1701 Evelyn took his wife to Dr. Hans Sloane for consultation over a 'tedious' but unnamed illness (v.456).

Evelyn appears to have been a friend or at least on terms of acquaintance with most of the leading physicians of his time. Some were friends from Paduan days such as George Croydon (iii.442) and George Rogers, of whom the latter presented Evelyn with a copy of his Harveian Oration of 1681 that contained among the congratulatory pieces a short Latin poem by the recipient (iv.291). Although Evelyn was well acquainted with many of the orators he mentions attendance at only one oration, that of Nathan Paget in 1664, apparently on the invitation of Edward Alston, then President of the College of Physicians (iii.379). Actually, however, Evelyn had a good deal to do with that body. In 1652 at the urging of Dr. Scarburgh he lent his anatomical panels so that Scarburgh might lecture about them at the College, then at Amen Corner (iii.77-78). In 1662 the librarian, Dr. Christopher Merret, invited Evelyn to the College where he mentions having seen the library, museum, and that statue of William Harvey that was to be destroyed in the Great Fire (iii.337-38); ${ }^{9}$ and in the following year he was again at the College with Merret (iii.364).

In 1678 Evelyn took the Portuguese Ambassador to see the new College of Physicians in Warwick Lane, designed by Robert Hooke (iv.133), and in 1683 he

Life of Mrs. Godolphin, ed. E. W. Harcourt, London, 1888, p. $145 \mathrm{f}$.

- Geoffrey Keynes, The Portraiture of William Harvey, London, 1949, pp. 6, 21-22. 


\section{John Evelyn and Medicine}

attended at least one of Walter Charleton's lectures on the heart that were to be published later in the same year as Three anatomic lectures (iv.308). It was also in 1683 that he dined there with Sir Thomas Millington and Dr. Whistler, 'the most facetious man in nature', when Evelyn's advice was sought regarding the location of the library (iv.307) that was so badly needed to house the collection of the Marquis of Dorchester. He had long known Whistler, at least from 1662 when that physician had spoken at a meeting of the Royal Society (iii.341), and no doubt had often met him socially thereafter at small dinners of congenial members such as one in 1676 at which Robert Boyle, Sir Christopher Wren and Sir William Petty were also present (iv.84). That the 'facetious' Whistler had played fast and loose with College funds, as became evident after his death in 1684, must have been an unpleasant shock, but Evelyn, who undoubtedly heard of the matter, spared the memory of an old friend by silence in his Diary.

A few other medical acquaintances were George Joyliffe whom Evelyn had known since at least 1649 (ii.551), and in 1657 he was Evelyn's physician during a brief indisposition (iii.186). Since Joyliffe had been a participant in that celebrated lithotomy performed on Samuel Pepys, he represented a link between the two diarists before they actually met. Evelyn first mentioned Sir William Petty in 1661 (iii.304), and in recalling a dinner given by Petty in 1675 he referred to his host's share in the resuscitation of Anne Greene, 'recovering a poore wench that had ben hanged for felonie' (iv.56-57). The incident of the young servant-girl hanged at Oxford, carted off for dissection, discovered to be still living and resuscitated by Petty and Thomas Willis seems to have made a strong impression on Evelyn since twenty-eight years later in a letter to William Wotton he referred to the incident as one of the noteworthy events in Petty's career. ${ }^{10}$ It would be possible to extend the list of Evelyn's medical friends to considerable length, but merely one more will be mentioned, Thomas Hoy who represents an instance of a physician appealing to Evelyn for assistance, presumably aware of the latter's sympathetic interest in the medical profession. In 1698 Hoy prevailed upon Evelyn to use his influence to gain him appointment as professor of physick at Oxford (v.298). Since the supplicant's career displayed nothing especially noteworthy, the episode is indicative of the depressed condition of academic medicine at the time and as well Evelyn's failure to recognize the need for a strong medical faculty at the universities. He not only sought political support for the appointment as he had been requested to do, but on his own initiative also approached the Archbishop of Canterbury. His efforts were successful and Hoy occupied the chair of medicine for approximately two decades.

As was mentioned earlier, Evelyn's interest in medicine was also prompted by his humanitarian concern for the well-being of the people as a whole, and it was this concern that explains his great and thorough interest in hospitals. The first active manifestation of such humanitarianism is to be found in his booklet Fumifugium of 1661 , a proposal of as much cogency today as in the seventeenth century. Primarily his concern was with the constant pall of smoke that hung over and pervaded London's atmosphere. 'That this glorious and Antient City, which from Wood might be rendred Brick, and (like another Rome) from Brick made Stone and Marble . . .

10 Memoirs, op. cit., III, p. 393. 


\section{D. O'Malley}

should wrap her stately head in Clowds of Smoake and Sulphur, so full of Stink and Darknesse, I deplore with just indignation'.

It produced not only a nuisance but a threat to the health of the people, so that, as Evelyn continued, 'old Par, who lived in health to an hundred and fifty years of age, was not so much concerned with the change of diet (as some have affirmed) as with that of the aer, which plainly withered him, and spoyled his digestion in a short time after his arrival in London'. Moreover, he declared, the problem was readily soluble simply through the removal of the worst smoke-producing industries such as soap-factories and breweries. Yet the ugliness of the entire congested city bothered him as well. 'That the Buildings should be composed of such Congestion of mishapen and extravagant Houses: That the Streets should be so narrow and incommodious in the very Center, and busiest places of Intercourse; That there should be so ill and uneasie a form of Paving under foot, so troublesome and malicious a disposure of the Spouts and Gutters overhead, are particulars worthy of Reproof and Reformation; because it is hereby rendered a Labyrinth in its principal passages, and a continual wet day after the storm is over.'

Unfortunately Evelyn's criticisms as well as his far-sighted proposals for improvement, including the planting of a belt of sweet-smelling trees and shrubs about the city, came to nothing.

His first real opportunity for effective as well as worthwhile service came as a result of the Anglo-Dutch War of 1664 when he was appointed one of the four commissioners for the medical care of English seamen and Dutch prisoners. His district of Kent and Sussex was the largest and most active of the four that were established and made his duties the more time-consuming and exhausting since he was compelled to a fairly constant routine of travel from one port to another. It was also perilous work since the faithful Evelyn kept to his post of duty despite the severity of the plague of 1665, a fact appreciated by Charles II whose offer of a knighthood was, however, politely refused by Evelyn. Certainly no one could have been more conscientious, and when the great fire of London broke out, his concern for the fate of two of the hospitals where a number of seamen were being treated, St. Bartholomew's and the Savoy, caused him to join actively in the work of checking the flames (iii.455-56). It was during his later service on this commission, after resumption of the war with the Dutch, that an overweighted conscience compelled him, although reluctantly, to watch that amputation of a seaman's leg in 1672 to which reference was made earlier.

It was inevitable that he would be consulted by Sir Stephen Fox, originator of the plan for Chelsea Hospital as a retreat for army pensioners, and it was as an enthusiastic supporter of this scheme for what Evelyn called 'Emerited Souldiers' (iv.269) that he no doubt recollected his visit to the similar institution in Amsterdam, which he described in his diary in 1641 as 'one of the worthiest things that I thinke the worlde can shew of that nature'. Invited to act as treasurer for Greenwich Hospital (v.209), a like foundation for seamen, Evelyn was equally enthusiastic, and together with Wren laid the foundation-stone in 1696 (v.249).

Whether or not Evelyn would have been a good physician if he had entered medicine professionally as a few, although not many, of the gentry did in his day, is a much 


\section{John Evelyn and Medicine}

too complicated question ever to have a sure answer. It is clear that his interest was strong, but his numerous other concerns would probably have made it impossible for him to have concentrated sufficiently intensively on this single subject. He was not always a friend to some of the practices of medicine, but he was definitely a wellwisher and supporter of the profession of medicine which, from his external viewpoint, he was able to imbue with an idealism and humanitarianism of which, unfortunately, some physicians of his time were unaware. His support was well worth having, a fact that seems to have been realized by the perspicacious, and in some measure English medicine of the seventeenth century, in its scientific, clinical, and social aspects, was the better for Evelyn's existence. 